\title{
HOUSE PRICES, DISPOSABLE INCOME, AND PERMANENT AND TEMPORARY SHOCKS
}

By

\author{
Patricia Fraser \\ School of Economics and Finance \\ Curtin University \\ \& \\ Martin Hoesli \\ University of Geneva \\ \& \\ Lynn McAlevey
}

Department of Finance and Quantitative Analysis, University of Otago

ISSN: 1835-9450

09.06 


\title{
House Prices, Disposable Income, and Permanent and Temporary Shocks
}

\author{
Patricia Fraser*, Martin Hoesli ${ }^{* *}$ and Lynn McAlevey***
}

\begin{abstract}
This paper specifies a two-variable system of house prices and income for New Zealand, the U.K. and the U.S., covering periods from 1973:4 through 2008:2. The analysis allows the identification of differences in house price-income relationships over sub-periods and, using a SVAR approach, compares the responses of house prices when faced with permanent and transitory shocks to income. It continues by decomposing each historical house price series into their permanent, temporary and deterministic components. Our results suggest that while real house prices have a long-run relationship with real income in all three economies, the responsiveness of house prices to innovations in income will vary over both time and markets depending on whether the income disturbances are viewed as permanent or temporary. The evidence suggests that New Zealand and U.K. housing markets are sensitive to both permanent and transitory shocks to income, while the U.S. market reacts to temporary shocks with the permanent component having a largely insignificant role to play in house price composition. In New Zealand, the temporary component of house prices has tended to be positive over time, pushing prices higher than they would have been otherwise; while in the U.K. both permanent and temporary components have tended to reinforce each other. Overall, there is no clear consistent global pattern regarding the importance of these shocks which implies that housing markets will react differently to the vagaries of global and domestic economic activity driving such shocks.
\end{abstract}

JEL Codes: R31, E64

Keywords: House prices, permanent income shocks, temporary income shocks, SVAR approach

\footnotetext{
* School of Economics and Finance, Curtin Business School, Curtin University of Technology, GPO Box U1987, Perth WA 6845 and University of Aberdeen Business School, University of Aberdeen, Edward Wright Building, Dunbar Street, Aberdeen AB24 3QK, , email: P.Fraser@cbs.curtin.edu.au

** University of Geneva (HEC and SFI), 40 boulevard du Pont-d'Arve, CH-1211 Geneva 4, Switzerland, University of Aberdeen Business School, University of Aberdeen, Edward Wright Building, Dunbar Street, Aberdeen AB24 3QK, Scotland, and Bordeaux Ecole de Management, 680 cours de la Libération, F-33405 Talence cedex, France, email: martin.hoesli@unige.ch (contact author) *** Department of Finance and Quantitative Analysis, University of Otago, PO Box 56, Dunedin, New Zealand, email: $\underline{\text { Imcalevey@business.otago.ac.nz }}$
}

We thank Donald Haurin and Elias Oikarinen for very helpful comments on an earlier draft. 


\section{Introduction}

It is a stylized fact, supported by empirical research, that a major determinant of house prices is income. Indeed many researchers have utilized this axiom as a basis from which to build theoretical and empirical models. Traditionally, income is included as a key determining factor in equilibrium pricing models, along with variables such as employment, constructions costs, and interest rates (Bourassa, Hendershott and Murphy, 2001, Capozza, Hendershott and Mack, 2004). Variations on the present value model have also been the focus of attention in deriving fundamental values of house prices (see e.g. Clayton, 1996, Chan, Lee and Woo, 2001, Fraser, Hoesli and McAlevey, 2008a). The latter studies are motivated by the fact that current and future ‘affordability’ of residential housing has become a strategic issue to informing policy at both microeconomic and macroeconomic levels of activity. More recent studies utilizing income discount modeling have incorporated forward-looking and dynamic characteristics in order to incorporate information regarding expectations on future income, with this being discounted at a, possibly time-varying, rate of return representing current and future states of the economy (see e.g. Fraser; Hoesli and McAlevey, 2008a).

However, one of the key assumptions underlying aforementioned formulations is that the price-income relationship is constant over time. This, however, is unlikely to be the case, as reported for instance by Malpezzi (1999) for various U.S. cities. This view is also supported by wide variations in estimates of reported income elasticities as measured by the average response of housing expenditure to income. Tse and Raftery (1999), for example, report elasticity estimates for Hong Kong which range from 0.1 to 1.4 depending on geographical area, socioeconomic factors, future income expectations as well as the time period under investigation.

One reason for the time-varying nature of the relationship may itself arise from the endogenous nature of house prices and income in that both variables are exposed to two (common) types of macroeconomic shocks: permanent or long-lasting shocks, e.g. supply-type disturbances such as those involving productivity or enduring statutory/regulatory changes, and temporary shocks e.g. demand-type disturbances such as cyclical fiscal or monetary changes. Generally, permanent shocks are those types of events which provide an impetus for rising/falling (non-stationary) long-term trends in house prices and income, while transitory shocks are those which drive 
(stationary) deviations from these long-term trends and therefore account for the mean-reverting behavior of real house price returns and real income growth. ${ }^{1}$

While shocks which impinge on income are likely to have much in common with those affecting house prices, the responsiveness of house prices to income disturbances may differ according to whether such shocks are viewed as being of a permanent or transitory nature. While the importance of permanent and temporary components of income has been consistently recognized in the housing literature (see, e.g., Lee, 1968, Horioka, 1988, Tse and Rafferty, 1999), the tendency has been to proxy these components indirectly by using, for example, household level data or consumption data, rather than recovering the permanent and temporary components directly from the jointly determined system of prices and income itself: it is this direct method of estimation which is a key aim of this study.

Consistent with recent studies, this paper proceeds by using time series methodologies on three major house-owning economies, namely the U.S., the U.K. and New Zealand (N.Z.). The homeownership rate in these countries is comparable and high (68\% for the U.K. and New Zealand and 66\% for the U.S.). ${ }^{2}$ These countries, however, vary in that the building regulations, zoning, and population density, among other things, are quite different. The U.K. has very strict regulations and is also the most heavily populated. Regulations are more lax in the U.S. and the country is also far less densely populated. This converts into significantly higher price elasticities of housing supply in the U.S. than in the U.K. (e.g., Catte et al., 2004). New Zealand is the least densely populated of the three countries, but building regulations are stricter than in the U.S. Moreover, construction labor shortages in periods of rapid growth due in part to emigration have led to construction being to some extent curtailed. There is empirical evidence to suggest that the supply elasticity, for Auckland in any case, is closer to that of the U.K. than that of the U.S. (Grimes et al., 2007).

The three countries differ also with respect to temporary influences on income. Using deviations from long-term trends, Fraser, Hoesli and McAlevey (2008b)

\footnotetext{
${ }^{1}$ The traditional view in the consumption-income literature is that permanent (temporary) shocks to income have a marginal propensity to consume (MPC) from permanent income close to unity while the MPC from transitory income is close to zero. Permanent (temporary) shocks are typically explained as shocks to non-capital (capital) income (see e.g. Carroll, 2001). However, it is not clear what this implies for house prices as householders have both consumption and investment motives for holding residential property and this may vary over time and region.

${ }^{2}$ Bourassa and Hoesli (2010).
} 
indicate that for the U.K., temporary components of income were predominately negative between 1984 through 2003, while for N.Z., with the exception of the midlate 1990s, income deviations from long-term trend were predominately positive. A similar exercise for the U.S. indicates that from 1984 through 1991, temporary components of income were positive, negative until 1998 and positive again until 2004.

Data from these three economies are first analyzed to examine whether a longrun stable relationship exists between real house prices and real disposable income and, if so, how prices (on average, over the short-run and long-run) respond to changes in income and how quickly these prices adjust to the long-run sustainable relationship. Unlike previous studies, the two elasticity measures along with the adjustment parameter are estimated simultaneously within an error correction equation. By abstracting from short-run deviations from possible jointly determined long-run relationships, not only does this initial analysis allow us to specify the nature of each of the two-variable systems, it also allows the identification of possible differences in the house price-income relationships over sub-periods.

While the above analysis is useful in determining the time series characteristics of the house price-income relationship, it is not however able to distinguish between the impact on house prices of permanent and transitory income shocks to each of the two-variable systems. Hence this study further adds to the existing literature by employing a version of the Blanchard and Quah (1989) (BQ) methodology which puts restrictions on the Bivariate Moving Average (BMAR) process to recover the permanent and temporary income disturbances driving the house price series. Such a method is useful as it allows us to model the relevant variable innovations within the economic model itself and is applicable to any series where time series behavior is jointly determined. We can therefore analyze the impact of permanent and temporary shocks to income on house prices and using a structural decomposition, analyze the time path of the permanent and temporary components of house prices in order to gauge the joint impact and importance of these two types of shocks on house prices over time.

Essentially, the two main objectives of the study, namely, to analyze the dynamic characteristics of the house price-income relationship over time and to assess the importance of common temporary and permanent shocks on historical 
house prices, has value-added in that it provides a comprehensive knowledge base on which market analysts and policy-makers can form forecasts and derive relevant policy decisions on the likely path of house prices. Not least, in light of (often recurring) crises in housing markets and the vagaries of domestic and world-wide economic activity it is important to gauge how prices in these three developed and major home-owning economies will behave when faced with different types of income shocks (see e.g. Goodhart and Hofmann, 2007; Oikarinen, 2009a).

The remainder of this paper is organized as follows. We first present our empirical framework, followed by a discussion of the data and some preliminary statistics. The empirical results are discussed next, while concluding remarks are contained in a final section.

\section{Empirical Method and Model}

As indicated above, our first task is to consider whether a long-run stable relationship exists between house prices and income, and if so, how house prices (on average) respond to changes in income and how quickly these prices adjust to the long-run sustainable relationship. To do this, we use cointegration tests and, if the null of no cointegration is rejected, model an error correction relationship which, when specified in a way which corrects for possible small sample bias, will provide simultaneously: Unbiased estimates of the average short-run and long-run responsiveness of house prices to changes in income, as well as the adjustment parameter to long-run equilibrium.

\subsection{Cointegration}

The usefulness of this methodology in the current analysis essentially comes down to determining the rank of the long-run impact matrix between real house prices and real disposable income. If this has rank, $r$, then there are $r$ cointegrating relationships between the variables in the system $\left(X_{t}\right)$, or, $n-r$ common stochastic trends, where $n$ is the number of variables in the system. The stochastic trends are the linear combinations of $X_{t}$, having the 'common' feature of not containing the levels of the error correction term in them (Gonzalo and Granger, 1995). In other words, they are the long-run forces that create the non-stationary property of the data.

The number of cointegrating vectors reveals the extent of integration of the variables in the system. In general terms, if $n-r=0$ or $r=n$ (full rank), we have the 
absence of any stochastic trends with all elements in $X_{t}$ being stationary, (I(0)), and cointegration is not defined (Gonzalo and Granger, 1995). If $n-r=n$ or $r=0$, there are no stationary long-run relationships among the elements of $X_{t}$. If $n-r=1$ or $r=$ $n-1$, there is a single common stochastic trend, hence a single long-run relationship that creates the non-stationarity of the data.

\subsection{Error Correction Model}

Evidence of cointegration between the two variables of interest implies we can use an error correction model (ECM) to estimate elasticities and associated adjustment parameters to long-run equilibrium. However, unlike most existing studies who use either the standard Engle and Granger (1987) method (Hort, 1998; Harter-Dreiman, 2004) or the Johansen (1988) approach (Holly and Jones, 1997; Meese and Wallace, 2003) to measure the equilibrium error, here we follow Banerjee et al. (1986), who point out that standard cointegrating regressions are likely to be subject to substantial small sample bias with the problem arising because the estimate of the constant in the equilibrium relationship may vary with the long-run growth rate of the independent variable (see also Gallin, 2006). Essentially, unless the long run growth rate of the independent variable is zero, in our case real disposable income, or long-run elasticities are equal to short-run elasticities, our prior knowledge of the long-run parameters are not unbiased, thus we do not have the necessary information to construct the traditional second-stage specification of an ECM, i.e. the disequilibrium error (see e.g. Thomas, 1996, pp. 385-386).

Banerjee therefore suggests carrying out the estimation of the long-run and short-run parameters in a single step. Assuming a first order disequilibrium relationship is observed:

$$
h p_{t}=b_{0}+b_{1} y_{t}+b_{2} y_{t-1}+\mu_{1} h p_{t-1}+\varepsilon_{t}
$$

with the estimating error correction equation:

$$
\Delta h p_{t}=\lambda \beta_{o}+b_{1} \Delta y_{t}-\lambda h p_{t-1}+\lambda \beta_{1} y_{t-1}+\varepsilon_{t}
$$

where $\Delta h p_{t}$ and $\Delta y_{t}$ denote changes in (ln) real house prices and (ln) real disposable income; $h p_{t-1}$ and $y_{t-1}$ are one period lagged (ln) levels of these variables. $\lambda$ is the adjustment parameter estimating the speed of adjustment to long-run equilibrium, $b_{1}$ is the estimated short-run elasticity and $\beta_{1}$ is the estimate of the long-run elasticity of 
house prices to income, $\varepsilon_{t}$ is the regression error. If higher order lags are deemed necessary, then equation (2) is adjusted accordingly.

\subsection{Structural VAR (SVAR)}

As discussed above, while the ECM is useful in gaining insight into the average propensities of house prices to respond to changes in income, it is unable to distinguish between the impact on house prices of permanent and transitory shocks to income emanating from the wider economy. It is known that in a univariate model there is no unique way to decompose a variable into its permanent and temporary components (Enders, 1995). We employ the Blanchard and Quah (1989) (BQ) method and follow Lee (1995), Hess and Lee (1999) and, more recently, Fraser, Hoesli and McAlevey (2008a) in placing restrictions on the Bivariate Moving Average Representation process to recover the permanent and temporary shocks (see also Bloch, Fraser and MacDonald, 2009). Such decomposition is useful as it allows us to model the series disturbances using economic analysis and can be applied to any series whose time series behaviour is jointly determined. The model is briefly described below.

Fraser, Hoesli and McAlevey (2008a) develop a dynamic present value model of house prices, first applied to stock prices and dividends by Campbell and Shiller (1989), to the relationship between aggregate house prices and national real disposable income. Starting from the assumptions that equilibrium rent is the rent renters are willing to pay and this is constrained by income and, real net rental income is proportional to real disposable income, the authors express the equilibrium real value of the aggregate housing stock as a constant proportion of the expected future value of real disposable income. In particular they show that the house price-income ratio can be expressed as:

$$
(h p-y)_{t}=\sum_{j=0}^{\infty} \mu^{j} E_{t} \Delta y_{t+j}-\sum_{j=0}^{\infty} \mu^{j} E_{t} r_{t+j}+c^{*}
$$

where $c^{*}$ is a constant, $(h p-y)_{t}$ is the (ln) house price-real disposable income ratio, $\Delta y_{t+j}$ is real income growth, $r_{t+j}$ is the real discount rate, $\mu^{j}$ is a linearization constant and $E_{t}$ is the expectations operator. Following Lee (1995) if we then assume that the expected discount rate is linearly related to the rate of expected income growth, we have: 
$E_{t}\left(r_{t+j}\right)=\alpha E_{t} \Delta y_{t+j}+k, \alpha>0$

where $\alpha$ and $k$ are constants. Substituting (4) into (3) gives:

$(h p-y)_{t}=E_{t} \sum_{j=0}^{\infty} \mu^{j}(1-\alpha) \Delta y_{t+j}+c \quad$ where $c=-\left[c^{*}+\frac{k}{1-\mu}\right]$

and if we model income as the sum of permanent and temporary components which respond to shocks, we can then impose restrictions on the jointly determined process.

According to a form of Wold's decomposition theorem (Hannan, 1970), if a time series of growth rates of real house prices, $\Delta h p_{t}$, and real disposable income, $\Delta y_{t}$, are stationary processes, and the levels of real house prices, $h p_{t}$, and real disposable income, $y_{t}$, are cointegrated, we can model them as past values of themselves in the form of a Bivariate Vector Autoregression (BVAR) of the form $\Delta h p_{t},(h p-y)_{t}$, and from this derive a Bivariate Moving Average Representation (BMAR), that will have restrictions consistent with the ability to identify the permanent and temporary components of house prices.

The restrictions imposed on the BMAR can be illustrated as follows. Consider a two variable vector autoregression (BVAR) $) z_{t}$ consisting of $\Delta h p_{t}$ and $(h p-y)_{t}$ :

$$
z_{t}=\left[\begin{array}{l}
\Delta h p_{t} \\
(h p-y)_{t}
\end{array}\right]=\left[\begin{array}{l}
\sum_{k} a_{11}^{k} \Delta h p_{t-k-1}+\sum_{k} a_{12}^{k}(h p-y)_{t-k-1}+u_{1, t} \\
\sum_{k} a_{21}^{k} \Delta h p_{t-k-1}+\sum_{k} a_{22}^{k}(h p-y)_{t-k-1}+u_{2, t}
\end{array}\right]
$$

where $u_{1, t}$ and $u_{2, t}$ are observed residuals.

In more compact form:

$$
z_{t}=A(L) z_{t-1}+u_{t}
$$

where $A(L)=\left[A_{i j}(L)\right]=\sum_{k} a_{i j}(k) L^{k-1}$ for $i, j=1$ and 2 with $\sum_{k} \equiv \sum_{k}^{\infty}$;

$$
\begin{aligned}
& \mu_{t}=\left[\mu_{1, t}, \mu_{2 t}\right]^{\prime}=z_{t}-E\left(z_{t} \mid z_{t-s}, s>1\right) ; \\
& \operatorname{VAR}\left(u_{t}\right)=\Omega=\sigma_{i j} \text { for } i, j=1 \text { and } 2 .
\end{aligned}
$$

Hence $u_{t}$ is a non-orthonormalized innovation in $\mathrm{z}_{t}$.

Since the permanent $\left[e_{t}^{p}\right]$ and transitory $\left[e_{t}^{t}\right]$ shocks are unobservable, the problem is to recover them from the VAR estimation. By the Wold representation 
theorem, there exists a bivariate moving average representation (BMAR) of $z_{t}$ which is obtained by inverting the BVAR of $z_{t}$ :

$$
z_{t}=\left[\begin{array}{l}
\Delta h p_{t} \\
(h p-y)_{t}
\end{array}\right]=\left[\begin{array}{l}
\sum_{k} c_{11}^{k} e_{t-k}^{p}+\sum_{k} c_{12}^{k} e_{t-k}^{t} \\
\sum_{k} c_{21}^{k} e_{t-k}^{p}+\sum_{k} c_{22}^{k} e_{t-k}^{t}
\end{array}\right]
$$

or

$$
z_{t}=C(L) e_{t}
$$

where $C(L)=\left[C_{i j}(L)\right]=\sum_{k} c_{i j}(k) L^{k}$ for $i, j=1$ and 2, and $e_{t}=\left[e_{t}^{p}, e_{t}^{t}\right]^{\prime}$, with the two innovations in $e_{t}$ being serially uncorrelated by construction and contemporaneously uncorrelated by orthonormalization with the variance of the vector, $e_{t}=\left[e_{t}^{p}, e_{t}^{t}\right]^{\prime}=I$ : hence the structural innovations, $e_{t}$, have a covariance matrix which is an identity matrix.

The critical insight is that the BVAR residuals $u_{t}$, are composites of the structural innovations, $e_{t}$. Comparing the BMAR in (8) (or (9)) with the BVAR in (6) (or (7)), estimates of $C(L)$, can be obtained by noting that:

and

$$
C^{o} e_{t}=u_{t}
$$

$$
z_{t}=C(L) e_{t}=[I-A(L) L]^{-1} \mu_{t}
$$

where $C^{o}=\left[c_{i j}^{k}\right]$ with $k=0$ and:

$$
C(L)=[I-A(L) L]^{-1} C^{o} \text {. }
$$

Hence, given an estimate of $A(L)$, we require an estimate of $C^{o}$ to calculate $\mathrm{C}(L)$, which is achieved by taking the variance of each side of (10):

$$
C^{o} C^{o}=\Omega=\left[\sigma_{i j}\right] \text { for } i, j=1 \text {, and } 2 .
$$

The relationships between the BVAR and the BMAR provide three restrictions for the four elements of $C^{o}$ so we need one additional restriction to just identify the four elements of $C^{o}$ (see Blanchard and Quah, 1989). This is:

$$
\sum_{k} c_{12}^{k}=0
$$


The moving average coefficient $c_{12}^{k}$ measures the effect of $e_{t}^{t}$ on $\Delta h p_{t}$ after $k$ periods and $\sum_{k} c_{12}^{k}$ denotes the cumulative effect of $e_{t}^{t}$. Setting $\sum_{k} c_{12}^{k}=0$, therefore requires that the innovation $e_{t}^{t}$ does not permanently influence house prices. Essentially, the coefficients $c_{i j}^{k}$ in (12) represent shocks in particular variables and because $e_{t}$ is serially and contemporaneously uncorrelated, we can allocate the variance of each element in $z_{t}$ to sources in elements of $e_{t}$ and this forecast error decomposition can be used to measure the relative importance to house prices of permanent and temporary shocks to income. Further, the estimated change in the temporary component $\left(c_{12}(L) e_{t}^{t}\right)$ can then be cumulated to get the transitory component of the house price series itself. The same procedure can be carried out to get the permanent component and provides a decomposition of the historical values of the house price series into those arising from the accumulated effects of current and lagged temporary and permanent shocks. The deterministic component is then the sum of the permanent and temporary components subtracted from the house price series. ${ }^{3}$

\section{Data and Preliminary Statistics}

\subsection{Data}

The data covers quarterly periods for N.Z., from 1973:4 through 2008:1; for the U.K., from 1973:4 through 2008:2; and for the U.S. from 1975:1 through 2008:2. N.Z. house prices were sourced from Quotable Value New Zealand, and the Reserve Bank of New Zealand. The U.K. index is the Nationwide index, while the FHFA (Federal Housing Finance Agency) index (formerly the OFHEO index) is used for the U.S. These indices measure changes in house prices and are adjusted for the quality of properties that transact (repeat measures of prices and/or assessed values are used in N.Z. and the U.S., while the hedonic method is used for the U.K. index). Disposable income and inflation data were collected from Statistics New Zealand and the Reserve Bank; the online National Statistical Office database facility and the Federal Reserve

\footnotetext{
${ }^{3}$ While this study is interested in the impact of common shocks to house prices and income, other influences specific to housing markets such as zoning laws and planning restrictions will also impact on the permanent component of prices (see e.g. DiPasquale and Wheaton, 1994; Malpezzi, 1999; Meen, 2002; Herring, 2006; Goodhart and Hofmann, 2007; Mayer and Hubbard, 2008). Such influences are not modelled here but are captured by the deterministic component of house prices.
} 
Economic Database (FRED) for N.Z., the U.K., and the U. S., respectively. House price data and disposable income data were then inflation adjusted hence are analyzed in real values.

\subsection{Preliminary Statistics}

Table 1 provides some summary statistics for key variables of interest, namely: real housing returns; real house price-disposable income ratios; and real disposable income growth rates, for N.Z., the U.K., and the U.S. They indicate that over the periods of analysis the quarterly average real capital gain on housing for N.Z. was $2.3 \%$, for the U.K. $2.1 \%$ while for the U.S. this was $1.4 \%$, the latter being achieved with relatively less ex post risk as measured by sample standard deviations. With the exception of the returns from the N.Z. market, J-B statistics cannot reject the null hypothesis of the normality of housing returns. The significance of non-normal real returns for New Zealand may well be a reflection that over the period 1970-2005 it experienced a relatively high number of housing peaks (van den Noord, 2006).

The mean price-income multiple is highest for N.Z., at circa 141\%, followed by the U.K. at circa $125 \%$. and at circa $53 \%$ for the U.S., indicating that, over the period, U.S. real disposable income was relatively high, while that for the U.K., and N.Z., was low, relative to house prices. Hence, it would appear that average house prices were more 'affordable' in the U.S. than in the U.K. or N.Z. ${ }^{4}$ At $3.2 \%$ per annum, average real disposable income growth rates were also higher for the U.S. than for N.Z. or the U.K., which were both $2.4 \%$ per annum. ${ }^{5}$

Visual inspection of the graphs involving real housing returns and real disposable income (not reported) suggested the relationships were not constant over time. To investigate this further, Table 2a shows simple correlations between the two variables over the full sample period, while Tables 2b and 2c show the correlation over two sub-samples: the first sub-sample ending in the fourth quarter of 1990, while the second sub-sample covers the period from the first quarter of 1991 to the end of the sample period. While the sign on the U.K. relationship remains consistent

\footnotetext{
${ }^{4}$ While the start dates of the analyses differ for each of the markets by a maximum of six observations, there is no qualitative difference to results when analyzed over a common sample. For the U.K., the average price-income ratio over the same sample period as the U.S. was circa $129 \%$, while for N.Z. this was $146 \%$.

${ }^{5}$ The real income growth rate for the U.K. over the same sample period as the U.S. remained at $2.4 \%$ and for N.Z. this was $2.3 \%$.
} 
(although magnitudes change), for N.Z. we see a shift in the sign on the degree of association between housing returns and income: going from negative in the first subsample, to positive in the second sub-sample. The positive sign in the second time period could be a consequence of financial liberalization which had the potential to lead to a much stronger response of house prices to income shocks. The full sample correlation in the New Zealand case is therefore influenced by the correlation in the first period. In this period, the economy was still highly regulated, access to mortgage finance was in fact an expression of monetary policy in the sense that interest rates were capped or regulated. Moreover, in 1981 and 1982, a wage freeze was in place, while the period 1975-1980 saw a key driver of real house prices, namely population growth, essentially flat. Thus it is likely that New Zealand would have experienced a change in the housing market dynamics during the period under investigation.

The U.S. correlations also change sign over the two sub-sample periods, but this time the degree of association goes from positive in the first sub-sample to negative in the second sub-sample, a feature which may have as its source in interactions between changing credit conditions and the slump and subsequent recovery in economic activity prevalent over this period. Note, however, that except for the U.K., and for N.Z. in one instance, these correlations do not exhibit statistical significance which itself indicates a closer examination of the dynamics of the house price-income relationship is warranted.

Overall, the time-varying nature of the return-income relationship suggests that the method of analysis utilized to examine the impact of common permanent and transitory shocks should take into account the interactions between prices and income, a feature which cannot be captured by reduced form models.

\section{Empirical Results}

\subsection{Cointegration Tests}

Evidence of cointegration between house prices and income allows us to assess the time series characteristics of their long-run relationship which in turn aids the specification of the structural VAR estimated below. In every case, standard unit root tests could not reject the null hypothesis that the levels of the house price and income series were non-stationary, i.e. (I(1)). We report the cointegration results for the full sample periods in Table 3, where, for the U.K. and U.S., both the Trace and 
Eigenvalue tests convincingly reject the null of no cointegration and while the reported p-values are not as extreme for N.Z., the null remains convincingly rejected at the $5 \%$ level. ${ }^{6}$ Overall, the implication is that the two-variable SVAR below should be specified as: $\Delta h p_{t},\left(h p_{t}-y_{t}\right)$.

\subsection{Error Correction Models}

As discussed in section 2, evidence of cointegration between house prices and income implies we can use an ECM to estimate simultaneously short and long-run elasticities and associated adjustment parameters to long-equilibrium status between the two variables. Hence, further to the above discussion, we report the short-run and long-run elasticities and adjustment parameters estimated in a single step, with the optimal model for all countries being a second order disequilibrium model (as indicated by standard lag length criteria and white noise residuals). As previous evidence suggests that these parameters are unlikely to be constant over time, we report in Tables $4 \mathrm{a}$ and $4 \mathrm{~b}$ the results for both sub-samples. Notably, the quarterly adjustment of the disequilibrium gap between house prices and income tends to be greater in the second sub-period than in the first implying a higher proportion of householders moved house in the second period than in the first. This is particularly the case for the U.K. market and, to a lesser extent, the N.Z. market. Tabulated below is the percentage disequilibrium error gap remaining after 5 years in each of the two sub-samples:

\% Gap Remaining After 5 Years

\begin{tabular}{|c|c|c|}
\hline & Sub-Sample 1 & Sub-Sample 2 \\
\hline N.Z. & 62 & 45 \\
\hline U.K. & 85 & 34 \\
\hline U.S. & 46 & 41 \\
\hline
\end{tabular}

One possible explanation for this may be the increased efficiency of housing markets over time. The gaps remain large in the second period, possibly suggesting

\footnotetext{
${ }^{6}$ We also tested the null of no cointegration over two sub-samples with the break being 1991Q1. For all markets and time periods, the null hypothesis of no cointegration between house prices and income was rejected, albeit in some cases trend assumptions were modified which in turn suggests that the behavior of cointegrating relations differed over the two sub-periods.
} 
that although efficiency has increased it is by no means perfect. Further, the U.S. results over the two sub-samples would indicate that this market is relatively more efficient in reducing the disequilibrium error - a feature which may be related to the fact that the U.S. market is a larger and more liquid market than its counterparts in the U.K. and N.Z.

With the exception of the U.K. during the first sub-sample, long-run elasticities tend to be higher than their short-run equivalents and indeed only the short-run response for the U.K. is statistically significantly different from zero (not reported). A possible explanation is the two-way interaction between credit availability and housing prices which will increase the elasticity in the long run (Oikarinen, 2009b). This is particularly noticeable for N.Z. during the first sub-sample where the long-run response is particularly high at $8.8 \%$ and may be related to the regulatory regime in operation in N.Z. at this time with effective access to mortgage finance being centrally controlled. ${ }^{7}$ In general, however, the dominance of long-run elasticities is largely consistent with the evidence from the literature which suggests first an under reaction of prices (i.e., low short-run elasticities, then an overshooting after 1-4 years and eventually convergence toward the long-run relationship (Harter-Dreiman, 2004; Lamont and Stein, 1999; Capozza, Hendershott and Mack, 2004; Oikarinen, 2009a). On the other hand, the results for the U.K. suggest that the relatively high short-run elasticity reported for the first sub-sample may be related to the heavily discounted sales of public housing stock to sitting tenants which generally could be financed on very favorable terms. Long-run price responses to income were less for N.Z. in the second time period, were greater for the U.K., while the U.S. exhibited a fairly stable long-run response.

\subsection{Structural VAR (SVAR)}

We now turn to an analysis of the dynamic implications of the model by examining the structural impulse response functions (IRFs) which, in Figures 1a through 1c, picture the response of the level house prices to a (positive) one standard deviation

\footnotetext{
${ }^{7}$ There was a 'cap' on mortgage finance in N.Z. during this period which is likely to have prevented higher income being transmitted to house prices in the short-run but adjustment taking place in the long-run. Fraser, Hoesli and McAlevey (2008a) also find that house prices and real income were out of alignment during this period.
} 
(S.D.) permanent and transitory shock to income along with their associated (Monte Carlo) confidence intervals. ${ }^{8}$

As shown in Figure 1a, for N.Z., the initial impact of permanent and temporary shocks is circa $1.6 \%$ and $1.1 \%$, respectively, with the impact of both shocks peaking at circa $3.5 \%$ and $3.1 \%$ at around 10 quarters later. While temporary shocks take a long-time to disappear (taking in excess of 80 quarters to become statistically insignificant), the results suggest that while both types of shocks have a significant impact on the level of house prices, the impact of permanent shocks is relatively greater.

The initial response of the U.K. to permanent and temporary income shocks is similar to that of N.Z. at approximately $1.4 \%$ and $1.6 \%$, peaking at circa $4.4 \%$ and 3.6\% some 10 and 12 quarters later. As with N.Z., the temporary component is slowly declining with the confidence intervals depicting that the impact of both types of shocks is statistically significantly (becoming statistically insignificant circa 80 quarters later). Again, the U.K. experience is that permanent shocks have a marginally greater impact on house price levels than temporary shocks.

For the U.S., we see a somewhat different dynamic response pattern emerging. The statistically significant initial response of house prices to a transitory shock is c. $0.9 \%$, peaking 12 quarters later at 2.2\% (and slowly declining thereafter reaching statistical zero circa 70 quarters later). A permanent shock, however, has a far lower initial (negative) response at approximately $-0.2 \%$, slowly reaching a peak of only $0.73 \%$. Notably, the permanent shock only becomes statistically significant at circa 28 quarters after the initial impact but the response of house prices to this shock remains small. Therefore not only is the response of U.S. house prices to income shocks relatively muted compared to the N.Z. and U.K. responses, but it is the temporary component which dominates with respect to both initial impact and size of impact. ${ }^{9}$ This reflects the fact of course that zoning laws and planning restrictions are tighter in the U.K. and N.Z. than in the U.S. There is much evidence in the literature, e.g. for the U.S., that the long-run income elasticity is greater in more supply restricted areas (Harter-Dreiman, 2004).

\footnotetext{
${ }^{8}$ Impulse response confidence intervals are based on 10,000 replications using the Monte Carlo Integration procedure in RATS.

${ }^{9}$ These time frames are broadly consistent with previous research such as Capozza, Hendershott and Mack (2004).
} 
We can also decompose the house price series themselves into their permanent and temporary components which enables us to compare and contrast the relative importance of such components over time. Following from the discussion of the SVAR in section 2, the permanent and temporary decompositions of the house price series are shown in Figures 2a though 2c.

Clearly, permanent and temporary income disturbances have impacted on N.Z., U.K. and U.S. house price movements in a different manner over the period. As Figure 2a depicts, the N.Z. temporary component, unlike those of the U.K. and U.S., was predominantly positive over the period, peaking in 1993, falling sharply until late 2002 and rising again to 2007. In contrast, in the early 1990s, there was a sharp negative change in the permanent component of house prices and the beginning of this decline in the permanent component of prices occurs during the global recessionary period of the early 1990s. Further, from the early 1990s through 1995, movements in the temporary component tend to be negatively correlated with the permanent component with the interaction between components keeping prices more stable than they would otherwise have been. It would appear that over this period demand-type influences did much to counteract the long-term influences on prices occurring in the 1990s. ${ }^{10}$ From 1996 to the end of the sample period, the permanent and temporary components are positively correlated both falling until 2001 and rising thereafter.

The U.K. results provide quite a different picture of price behavior to that of N.Z. Here it is the temporary component which is mainly negative over the period of analysis, therefore dragging prices down with the permanent component mainly positive. The exception to this is the period between late 1993 though 1997, where both temporary and permanent components were negative, thus reinforcing the dramatic fall in U.K. house prices over this period. Generally, in the U.K. the temporary component has kept house prices lower than they would have been in the absence of such shocks, although, as in N.Z., the latter part of the sample period has seen permanent and temporary components reinforcing the upward trend in real

\footnotetext{
${ }^{10}$ N.Z. has some unique characteristics in comparison with other OECD counties which may influence the behavior of prices with respect to income shocks over the period. N.Z. households hold a disproportionately high percentage of their assets in housing (Claus and Scobie, 2001) and by OECD, standards have extremely low holdings of direct and indirect equities (Bollard, 2006). Perhaps it is no surprise to find New Zealand to be different from the U.S. and U.K. Herring (2006, p. 8) quotes the IMF (2006, p. 84) report: "global factors appear to explain about 70 percent of house price movements in the United Kingdom and the United States, but only about 3 percent of house price movements in New Zealand”. New Zealand is clearly an outlier.
} 
prices. The permanent component began its recovery in the mid-1990s, somewhat earlier than the temporary component but given the very negative effect of the temporary component the overall result implies that house prices took a long time to recover from this period of what is commonly called 'negative equity'.

For the U.S., Figure 2c shows that from 1991 through 2002, the temporary component of house prices was negative and although reinforced by the permanent component had a much greater impact on price variability than the latter. Since 2002 and peaking in 2007, the temporary component has been well into the positive region. Historically, however, and in contrast to the N.Z and U.K. housing market, the U.S. market appears to be driven, by temporary rather than permanent shocks to income and this is particularly noticeable in the period since 2000. The recent increases in the temporary component may be explained by the impact of low interest rates and lax credit conditions in force in this period of substantial economic growth and associated real income rises. Figure 2c clearly indicates that since 2006 price decreases were to be expected and that these decreases were driven by temporary components.

Figures 3a though 3c provide combination graphs with deterministic components assigned to permanent components and graphed alongside temporary components and demeaned (log) house price returns. For N.Z., particularly in the 1980s and 1990s and since 2005, actual prices tend to be higher than the permanent and deterministic components combined would suggest with this deviation from longterm trend being driven by the temporary component which was predominantly positive over the period. This is in contrast with the results for the U.K. and the U.S. but is consistent with results from other international studies. Fraser, Hoesli and McAlevey (2008a), for example, report evidence to suggest that during the period 1988-2000, house prices in N.Z. were very close to their fundamental value as warranted by (total) real disposable income. This suggests that the positive temporary component of the prices series over this period had a role to play in the adjustment process towards fundamental value and therefore accounts for the observed mean reverting behavior of house price returns.

Over the period the upward movement in U.K. house prices can be seen to be driven by the combined permanent and deterministic series but the rises moderated by the temporary component which was mainly negative over the sample resulting in actual prices lying below their long-term trend over much of the period. Figure 3c shows that in the case of the U.S., the temporary component of prices also had a 
moderating effect on long-term trend price rises until 2004 and a reinforcing effect thereafter.

\section{Conclusion}

The aim of this paper is twofold. First, using time series analysis we specify the nature of a two-variable system of house prices and income for N.Z., the U.K. and the U.S., covering periods stretching from 1973:4 through 2008:2. Second, using an SVAR econometric approach, the study distinguishes between the initial impact on the levels of house prices of permanent and transitory shocks to the house price-income system for each of the countries in the sample and continues by decomposing historical house prices series into their permanent and transitory components.

Our results suggest that for N.Z., the U.K. and the U.S., a long-run relationship exists between house prices and income, although deviations from this stable relationship are likely to occur. We also report evidence to suggest that while longrun elasticities tend to dominate their short-run counterparts, they, along with the adjustment parameters, are not constant over time. We maintain that this may arise from the endogenous nature of house prices and income. Essentially, both house prices and income are exposed to two types of macroeconomic shocks: permanent or long-lasting shocks (e.g. supply-type disturbances) and temporary shocks (e.g. demand-type disturbances) and while shocks which impinge on income are likely to have much in common with those affecting house prices, the responsiveness of house prices to income disturbances may differ according to whether they are viewed as being of a permanent or transitory nature.

Utilizing an SVAR approach to house price-income relationships, we find that for N.Z. the response of house prices to permanent and temporary shocks to income was greater for the former although both types of shocks had a significant impact on prices with the effects of temporary shocks only declining very slowly. The response of U.K. house prices is similar to that of N.Z. in terms of magnitude and significance while the response of the U.S., although relatively muted, is dominated by temporary shocks with permanent shocks having no significant initial impact and very little lasting impact on the level of U.S. house prices. 
The method of analysis also allows us to decompose house prices into their permanent and temporary components. For N.Z. over the period, actual prices tended to be higher than the permanent and deterministic component alone would suggest with this gap being driven by the temporary component which was mainly positive over the period. This is in sharp contrast with the results for the U.K. and the U.S. For the former, over the period the upward movement in house prices can be seen to be driven by permanent and deterministic components of prices, with the rises being moderated by the temporary component which was mainly negative. Our results also show that in the case of the U.S. the temporary component dominates and, while the permanent component provided some minor moderation of prices, since 2002 a major driver of house prices has been the temporary or cyclical type influences impacting on income.

Thus the evidence reported here suggests that there is no clear consistent global pattern regarding the importance of permanent and temporary shocks to income on house prices which implies that housing markets will react differently to the vagaries of global and domestic economic activity driving such shocks - a feature which should be considered in the wider context of international and domestic macroeconomic policy decisions and implementation.

A number of caveats should be borne in mind when interpreting our findings. First, the analysis was undertaken at a highly aggregate level and a more disaggregated study examining the price behavior at regional levels (s.t. data availability) might arrive at different conclusions. Second, as this work estimates a bivariate model assigning the variations in house prices to income innovations, it cannot specifically account for other types of innovations unrelated to the income process. Future work may find it useful to consider for example, non-fundamental shocks and the response of house prices to this third type of innovation thus providing a clearer picture to emerge. Nevertheless, we feel that this paper can make a useful contribution to our understanding of the behavior of house prices with respect to their dynamic interaction with income in the markets analyzed. 


\section{References}

Banerjee, A., J.J. Dolado, D. F. Henry, and G.W. Smith (1986), 'Exploring Equilibrium Relationships in Econometrics Through Static Models: Some Monte Carlo Evidence', Oxford Bulletin of Economics and Statistics, 48, pp. 253-277.

Blanchard, O. J., and D. Quah (1989), 'The Dynamic Effects of Demand and Supply Disturbances’, American Economic Review, 79, pp. 655-673.

Bloch, H., P. Fraser and G. MacDonald (2009), 'Commodity Prices: How Important are Real and Nominal Shocks?' Centre for Research in Applied Economics Working Paper Series 200901. Bentley, Western Australia: Centre for Research in Applied Economics, Curtin Business School: PUB-CBS-SEFMT-46728 Z3.

Bollard, A. (2006), 'Kiwis Like Buying Houses More Than Buying Businesses' Reserve Bank Governor's Speech to Price-Waterhouse-Coopers Annual Tax Conference, 9 November.

Bourassa, S.C., P. H. Hendershott and J. Murphy (2001), 'Further Evidence on the Existence of Housing Market Bubbles', Journal of Property Research, 18, pp. 1-19.

Bourassa, S.C. and M. Hoesli (2010), 'Why Do the Swiss Rent?', Journal of Real Estate Finance and Economics, forthcoming.

Campbell, J.Y. and R.J. Shiller (1989), 'The Dividend-Price Ratio and Expectations of Future Dividends and Discount factors', Review of Financial Studies, 1, pp. 195-228.

Capozza, D.R, P.H. Hendershott and C. Mack (2004), 'An Anatomy of Price Dynamics in Illiquid Markets: Analysis and Evidence from Local Housing Markets', Real Estate Economics, 32, pp. 1-32.

Carroll, C.D. (2001), 'Precautionary Saving and the Marginal Propensity to Consume Out of Permanent Income': http://www.econ.jhu.edu/people/CCarroll/MPCPermBigNBER.pdf

Catte, P., N. Girouard, R. Price and C. André (2004), 'The Contribution of Housing Markets to Cyclical Resilience’, OECD Economic Studies No. 38.

Chan, H.L., S.K. Lee and K.Y. Woo (2001), 'Detecting Rational Bubbles in the Residential Housing Markets of Hong Kong’, Economic Modelling, 18, pp. 61-73.

Claus, I. and G. Scobie (2001), 'Household Net Wealth: An International Comparison’, New Zealand Treasury Working Paper, 01/19. 
Clayton, J. (1996), 'Rational Expectations, Market Fundamentals and Housing Price Volatility', Real Estate Economics, 24, pp. 441-470.

DiPasquale, D., and W. Wheaton (1994), 'Housing Market Dynamics and the Future of Housing Prices', Journal of Urban Economics, 35, pp. 1-27.

Enders, W. (1995), Applied Econometric Time Series, John Wiley \& Sons, Inc.

Engle, R.F. and C.W.J. Granger (1987), 'Cointegration and Error Correction: Representation, Estimation and Testing’, Econometrica, 55, pp. 251-276.

Fraser, P., M. Hoesli and L. McAlevey (2008a), 'House Prices and Bubbles in New Zealand' Journal of Real Estate, Finance and Economics, 37, pp. 71-91.

Fraser, P., M. Hoesli and L. McAlevey (2008b), 'A comparative analysis of house prices and bubbles in the U.K. and New Zealand' Pacific Rim Property Research Journal, 14, pp. 257-278.

Gallin, J. (2006), 'The Long-Run Relationship between House Prices and Income: Evidence from Local Housing Markets', Real Estate Economics, 34, pp. 417438.

Gonzalo, J. and C.W.J. Granger (1995), 'Estimation of Common Long Memory Components in Cointegrated Systems', Journal of Business and Economics Statistics, Vol. 13. pp. 27-35.

Goodhart, C. and B. Hofmann (2007), House Prices and the Macroeconomy: Implications for Banking and Price Stability, Oxford University Press, Oxford.

Grimes, A., A. Aitken, I. Mitchell and V. Smith (2007), 'Housing supply in the Auckland region 2000-2005', Centre for Housing Research, Wellington, New Zealand.

Hannan, E. J. (1970), Multiple Time Series, Wiley, New York.

Harter-Dreiman, M. (2004), 'Drawing Inferences About Housing Supply Elasticity from House Price Responses to Income Shocks', Journal of Urban Economics, 55, pp. 316-337.

Herring, R.J. (2006), 'Booms and Busts in Housing Markets: How Vulnerable is New Zealand?’: http://www.rbnz.govt.nz/research/fellowship/3324563.pdf

Hess, P.J. and Lee, B-S. (1999), 'Stock Returns and Inflation with Supply and Demand Disturbances.' The Review of Financial Studies, 12, pp. 1203-1218.

Holly, S. and N. Jones (1997), 'House Prices since the 1940s: Cointegration, Demography and Asymmetries', Economic Modelling, 14, pp. 549-565. 
Horioka, C.Y. (1988), 'Tenure Choice and Housing Demand in Japan’ Journal of Urban Economics, 24, pp. 258-309.

Hort, K. (1998), 'The Determinants of Urban House Price Fluctuations in Sweden 1968-1994’, Journal of Housing Economics, 7, pp. 93-120.

Johansen, S. (1988), 'Statistical Analysis of Cointegrating Vectors', Journal of Economic Dynamics and Control, 12, pp. 231-254.

IMF, (2006), World Economic Outlook, April, pp. 71-89.

Lamont, O. and J.C. Stein (1999), 'Leverage and House-Price Dynamics in U.S. Cities', RAND Journal of Economics, 30, pp. 498-514.

Lee, B.-S. (1995), 'The Response of Stock Prices to Permanent and Temporary Dividend Shocks', Journal of Financial and Quantitative Analysis, 30, pp. 122.

Lee, T.H. (1968), 'Housing and Permanent Income', Review of Ecomometrics and Statistics, 50, pp. 480-490.

Malpezzi, S. (1999), 'A Simple Error Correction Model of House Prices', Journal of Housing Economics, 8, pp. 27-62.

Mayer, C. and R.G. Hubbard (2008), 'House Prices, Interest Rates, and the Mortgage Market Meltdown’, working paper, Columbia Business School.

Meen, G. (2002), 'The Time-Series Behavior of House Prices: A Transatlantic Divide?', Journal of Housing Economics, 11, pp. 1-23.

Meese, R. and N. Wallace (2003), 'House Price Dynamics and Market Fundamentals: The Parisian Housing Market', Urban Studies, 40, pp. 1027-1045.

Noord van den, P. (2006), 'Are House Prices Nearing a Peak? A Probit Analysis of 17 OECD Countries’, OECD Economics Department Working Papers No. 488, 1 June 2006.

Oikarinen, E. (2009a), 'Interaction Between Housing Prices and Household Borrowing: The Finnish Case', Journal of Banking and Finance, 33, pp. 747756.

Oikarinen, E. (2009b), 'Household Borrowing and Metropolitan Housing Price Dynamics - Empirical Evidence from Helsinki', Journal of Housing Economics, forthcoming.

Thomas , R.L. (1996), Modern Econometrics. Financial Times Prentice Hall.

Tse, R.Y.C. and J. Rafferty (1999), 'Income Elasticity of Housing Consumption in Hong-Kong: A Cointegration Approach.' Journal of Property Research, 16:2, pp. 123-138. 
Table 1

Descriptive Statistics

\begin{tabular}{|c|c|c|c|}
\hline & Mean & $\begin{array}{l}\text { Standard } \\
\text { Deviation }\end{array}$ & $\begin{array}{c}\text { Jarque- } \\
\text { Bera } \\
(J-B)\end{array}$ \\
\hline $\begin{array}{l}\text { N.Z. } r_{h p, t} \\
\text { (real housing } \\
\text { returns) }\end{array}$ & 0.023 & 0.026 & $\begin{array}{r}15.563 \\
(0.000) \\
\end{array}$ \\
\hline $\begin{array}{c}\text { N.Z. py,t } \\
\text { (real house price- } \\
\text { disposable income } \\
\text { ratio) }\end{array}$ & 1.413 & 0.708 & $\begin{array}{l}14.101 \\
(0.001)\end{array}$ \\
\hline $\begin{array}{c}\text { N.Z. } \Delta y_{, t} \\
\text { (real disposable } \\
\text { income growth) }\end{array}$ & 0.006 & 0.012 & $\begin{array}{l}18.511 \\
(0.000)\end{array}$ \\
\hline $\begin{array}{l}\text { U.K. } r_{h p, t} \\
\text { (real housing } \\
\text { returns) }\end{array}$ & 0.021 & 0.026 & $\begin{array}{c}0.381 \\
(0.827) \\
\end{array}$ \\
\hline $\begin{array}{c}\text { U.K. py }{ }_{, t} \\
\text { (real house price- } \\
\text { disposable income } \\
\text { ratio) }\end{array}$ & 1.248 & 0.586 & $\begin{array}{c}5.917 \\
(0.052)\end{array}$ \\
\hline $\begin{array}{c}\text { U.K. } \Delta y, t \\
\text { (real disposable } \\
\text { income growth) }\end{array}$ & 0.006 & 0.012 & $\begin{array}{l}59.439 \\
(0.000)\end{array}$ \\
\hline $\begin{array}{l}\text { U.S. } r_{h p, t} \\
\text { (real housing } \\
\text { returns) }\end{array}$ & 0.014 & 0.011 & $\begin{array}{c}0.309 \\
(0.857)\end{array}$ \\
\hline $\begin{array}{c}\text { U.S. py, } \\
\text { (real house price- } \\
\text { disposable income } \\
\text { ratio) }\end{array}$ & 0.526 & 0.226 & $\begin{array}{c}2.733 \\
(0.255)\end{array}$ \\
\hline $\begin{array}{c}\text { U.S. } \Delta y, t \\
\text { (real disposable } \\
\text { income growth) }\end{array}$ & 0.008 & 0.098 & $\begin{array}{l}24.345 \\
(0.000)\end{array}$ \\
\hline
\end{tabular}

$r_{h p, t}$ is the real continuously compounded quarterly return from residential housing $p y_{, t}$ is the constructed price-real disposable income ratio and $\Delta y_{, t}$ is the rate of growth of real disposable income. The sample periods are: N.Z. 1973Q4 through 2008Q1; U.K. 1973Q4 through 2008Q2; U.S. 1975Q1 through 2008Q2. The figures in parenthesis below the $J-B$ statistics are marginal significance levels. 
Table 2a

Correlations of Real House Prices and Real Disposable Income: Full Sample

\begin{tabular}{|c|c|}
\hline $\begin{array}{c}\text { N.Z. } \\
\operatorname{corr}\left(r_{h p, t,,} \Delta y_{, t}\right)\end{array}$ & $\begin{array}{c}-0.008 \\
(0.923)\end{array}$ \\
\hline $\begin{array}{c}\text { U.K. } \\
\operatorname{corr}\left(r_{h p, t,,} \Delta y_{, t}\right)\end{array}$ & $\begin{array}{c}0.231 \\
(0.006)\end{array}$ \\
\hline $\begin{array}{c}\text { U.S. } \\
\operatorname{corr}\left(r_{h p, t,,} \Delta y_{, t}\right)\end{array}$ & $\begin{array}{c}0.082 \\
(0.345)\end{array}$ \\
\hline
\end{tabular}

$r_{h p, t}$ is the continuously compounded quarterly return from residential housing, and $\Delta y, t$ is the rate of growth of real disposable income. The sample periods are: N.Z. 1973Q4 through 2008Q1; U.K. 1973Q4 through 2008Q2; U.S. 1975Q1 through 2008Q2. The figures in parenthesis below the correlations are marginal significance levels.

Table 2b

Correlations of Real House Prices and Real Disposable Income: Sub-Sample 1

\begin{tabular}{|c|c|}
\hline N.Z. & \\
$\operatorname{corr}\left(r_{h p, t,} \Delta y_{, t}\right)$ & $\begin{array}{c}-0.137 \\
(0.264)\end{array}$ \\
\hline U.K. & \\
$\operatorname{corr}\left(r_{h p, t,} \Delta y_{, t)}\right.$ & 0.272 \\
& $(0.025)$ \\
\hline U.S. & \\
$\operatorname{corr}\left(r_{h p, t,} \Delta y_{, t)}\right.$ & 0.152 \\
& $(0.234)$ \\
\hline
\end{tabular}

$r_{h p, t}$ is the continuously compounded quarterly return from residential housing, and $\Delta y_{, t}$ is the rate of growth of real disposable income. The sample periods are: N.Z. 1973Q4: through 1990Q4; U.K. 1973Q4 through 1990Q4; U.S. 1975Q1 through 1990Q4. The figures in parenthesis below the correlations are marginal significance levels.

Table 2c

Correlations of Real House Prices and Real Disposable Income: Sub-Sample 2

\begin{tabular}{|c|c|}
\hline N.Z. & \\
$\operatorname{corr}\left(r_{h p, t,} \Delta y_{, t}\right)$ & 0.205 \\
& $(0.090)$ \\
\hline U.K. & \\
$\operatorname{corr}\left(r_{h p, t,} \Delta y_{, t}\right)$ & 0.209 \\
& $(0.082)$ \\
\hline U.S. & \\
$\operatorname{corr}\left(r_{h p, t,} \Delta y_{, t)}\right.$ & -0.009 \\
& $(0.942)$ \\
\hline
\end{tabular}

$r_{h p, t}$ is the continuously compounded quarterly return from residential housing, and $\Delta y_{, t}$ is the rate of growth of real disposable income. The sample periods are: N.Z. 1991Q1 through 2008Q1; U.K. 1991Q1 through 2008Q2; U.S. 1991Q1 through 2008Q2. The figures in parenthesis below the correlations are marginal significance levels. 
Table 3

Real House Price - Real Disposable Income Cointegration Tests

\begin{tabular}{|c|c|c|c|}
\hline & $\begin{array}{c}\text { Johansen } \\
\text { Trace Test of } \\
\text { No } \\
\text { Cointegration }\end{array}$ & $\begin{array}{c}\text { Johansen } \\
\text { Eigenvalue } \\
\text { Test of No } \\
\text { Cointegration }\end{array}$ & $\begin{array}{c}\text { Model } \\
\text { Specification } \\
\text { and Lags } \\
\text { Interval in } \\
\text { First } \\
\text { Differences }\end{array}$ \\
\hline N.Z. & 23.986 & 21.774 & $\begin{array}{c}\text { Intercept, No } \\
\text { Trend } \\
\end{array}$ \\
& cv: 20.262 & cv: 15.892 & $1-1$ \\
\hline prob: 0.014 & 36.189 & 29.464 & Intercept, No \\
& cv: 20.262 & cv: 15.892 & Trend \\
& prob: 0.000 & 0.000 & $1-1$ \\
\hline U.K. & 73.543 & 65.080 & Intercept, No \\
& cv: 20.261 & cv: 15.892 & Trend \\
& prob: 0.000 & $1-1$ \\
\hline
\end{tabular}

cv denotes critical values and prob denotes p-values. In each case the null hypothesis is that the variables are not cointegrated. The sample periods are: N.Z. 1973Q4 through 2008Q1; U.K. 1973Q4 through 2008Q2; U.S. 1975Q1 through 2008Q2. 
Error Correction Models with a Second Order Disequilibrium Relationship

$$
\begin{aligned}
r_{h p, t} & =b_{0}+b_{1} y_{t}+b_{2} y_{t-1}+b_{3} y_{t-2}+\mu_{1} r_{h p, t-1}+\mu_{2} r_{h p, t-2}+\varepsilon_{t} \\
& =\lambda \beta_{o}-\mu_{2} r_{h p, t-1}+b_{1} \Delta y_{t}-b_{3} \Delta y_{t-1}-\lambda r_{h p,-1}+\lambda \beta_{1} y_{t-1}+\varepsilon_{t}
\end{aligned}
$$

Table 4a

Short and Long Elasticity Measures w.r.t. a 1\% rise in Income: Sub-Sample 1

\begin{tabular}{|c|c|c|c|}
\hline & $\begin{array}{c}\text { Quarterly } \\
\text { Adjustment: } \\
\lambda\end{array}$ & $\begin{array}{c}\text { Short-Run } \\
\text { Elasticity: } \\
b_{1}\end{array}$ & $\begin{array}{c}\text { Long-Run } \\
\text { Elasticity: } \\
\beta_{1}\end{array}$ \\
\hline N.Z. & $-2.3 \%$ & $0.209 \%$ & $8.88 \%$ \\
\hline U.K. & $-0.8 \%$ & $0.554 \%$ & $0.34 \%$ \\
\hline U.S. & $-3.6 \%$ & $0.070 \%$ & $1.11 \%$ \\
\hline
\end{tabular}

$r_{h p, t}$ is the real continuously compounded quarterly return from residential housing and $\Delta y_{, t}$ is the rate of growth of real disposable income. The sample periods are: N.Z. 1973Q4 through 1990Q4; U.K. 1973Q4 through 1990Q4; U.S. 1975Q1 through $1990 \mathrm{Q} 4$.

Table 4b

Short and Long Elasticity Measures w.r.t. a 1\% rise in Income: Sub-Sample 2

\begin{tabular}{|c|c|c|c|}
\hline & $\begin{array}{c}\text { Quarterly } \\
\text { Adjustment: } \\
\lambda\end{array}$ & $\begin{array}{c}\text { Short-Run } \\
\text { Elasticity: } \\
b_{1}\end{array}$ & $\begin{array}{c}\text { Long-Run } \\
\text { Elasticity: } \\
\beta_{1}\end{array}$ \\
\hline N.Z. & $-3.8 \%$ & $0.109 \%$ & $2.13 \%$ \\
\hline U.K. & $-4.9 \%$ & $0.199 \%$ & $3.32 \%$ \\
\hline U.S. & $-4.1 \%$ & $-0.155 \%$ & $1.78 \%$ \\
\hline
\end{tabular}

$r_{h p, t}$ is the real continuously compounded quarterly return from residential housing and $\Delta y_{, t}$ is the rate of growth of real disposable income. The sample periods are: N.Z. 1991Q1 through 2008Q1; U.K. 1991Q1 through 2008Q2; U.S. 1991Q1 through $2008 Q 2$. 
Figure 1a

N.Z.

Response of N.Z. Real House Prices to a Permanent Shock

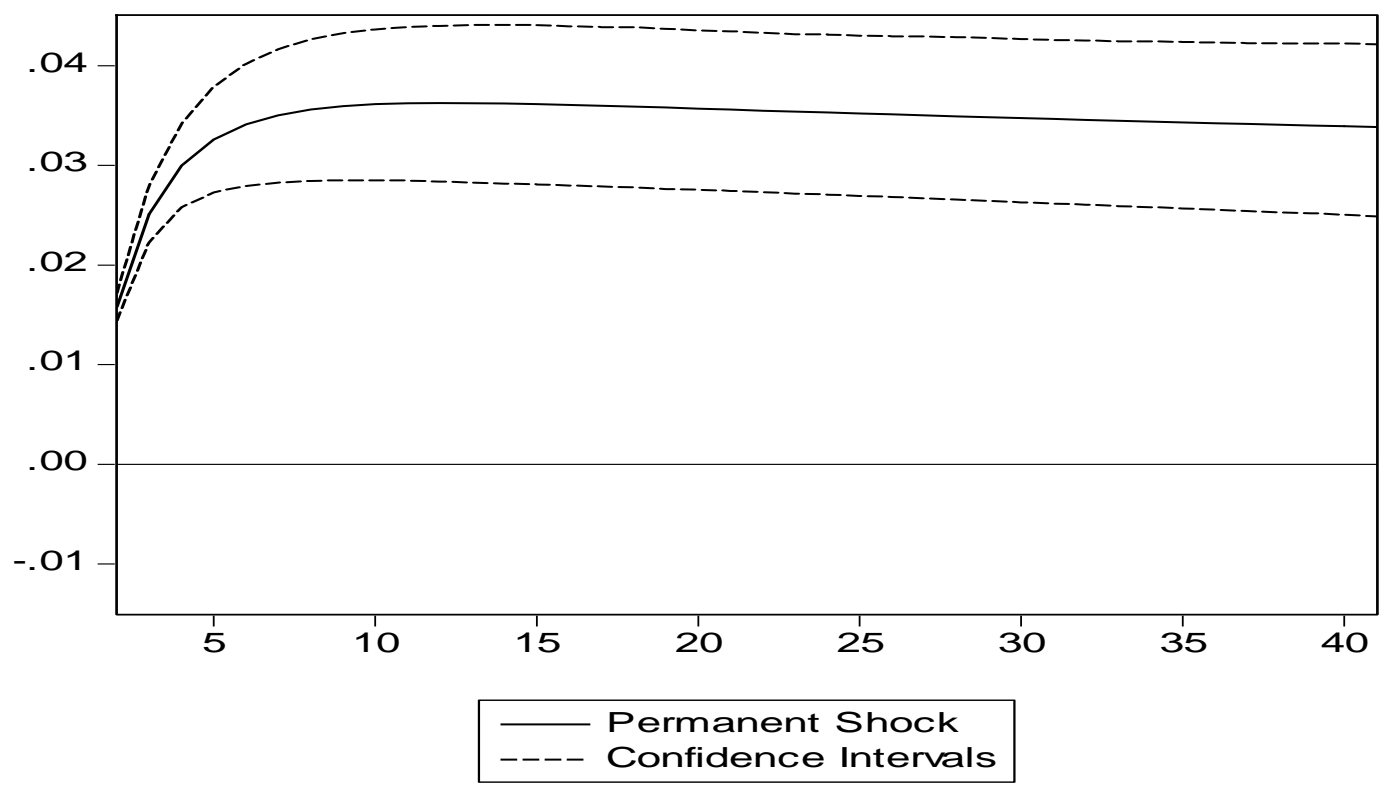

Response Of N.Z. Real House Prices to a Temporary Shock

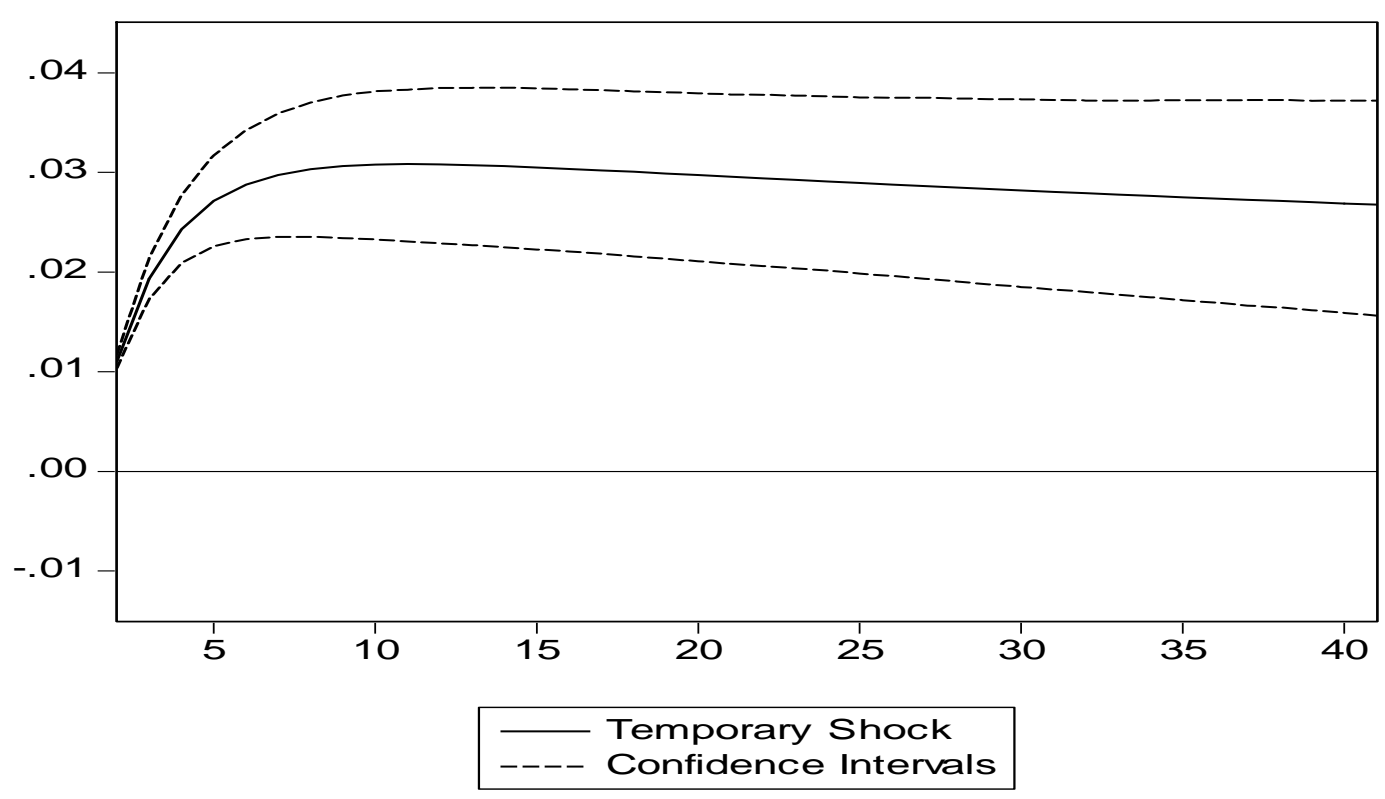


Figure 1b

U.K.

Response of U.K. Real House Prices to a Permanent Shock

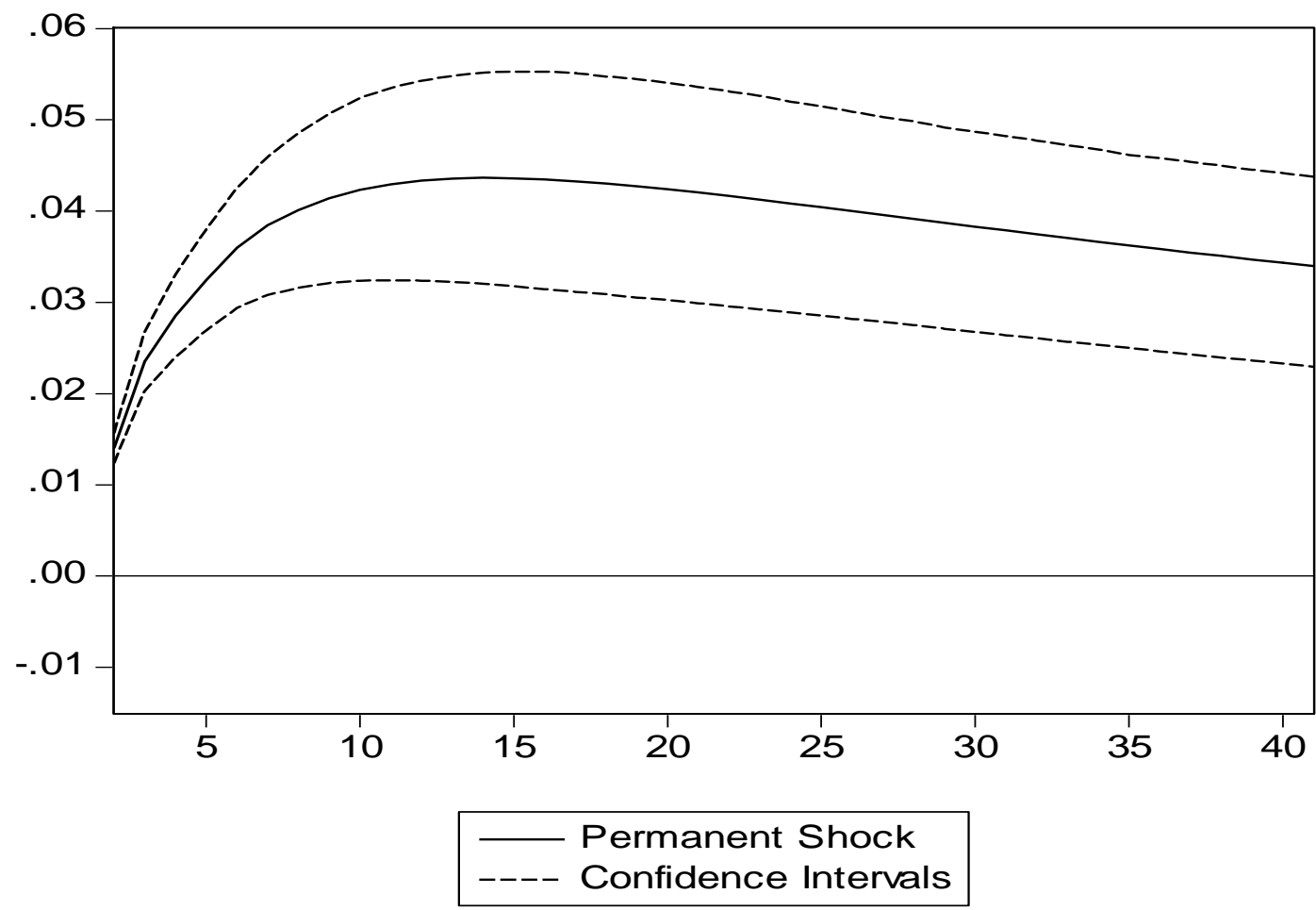

Response of U.K. Real House Prices to a Temporary Shock

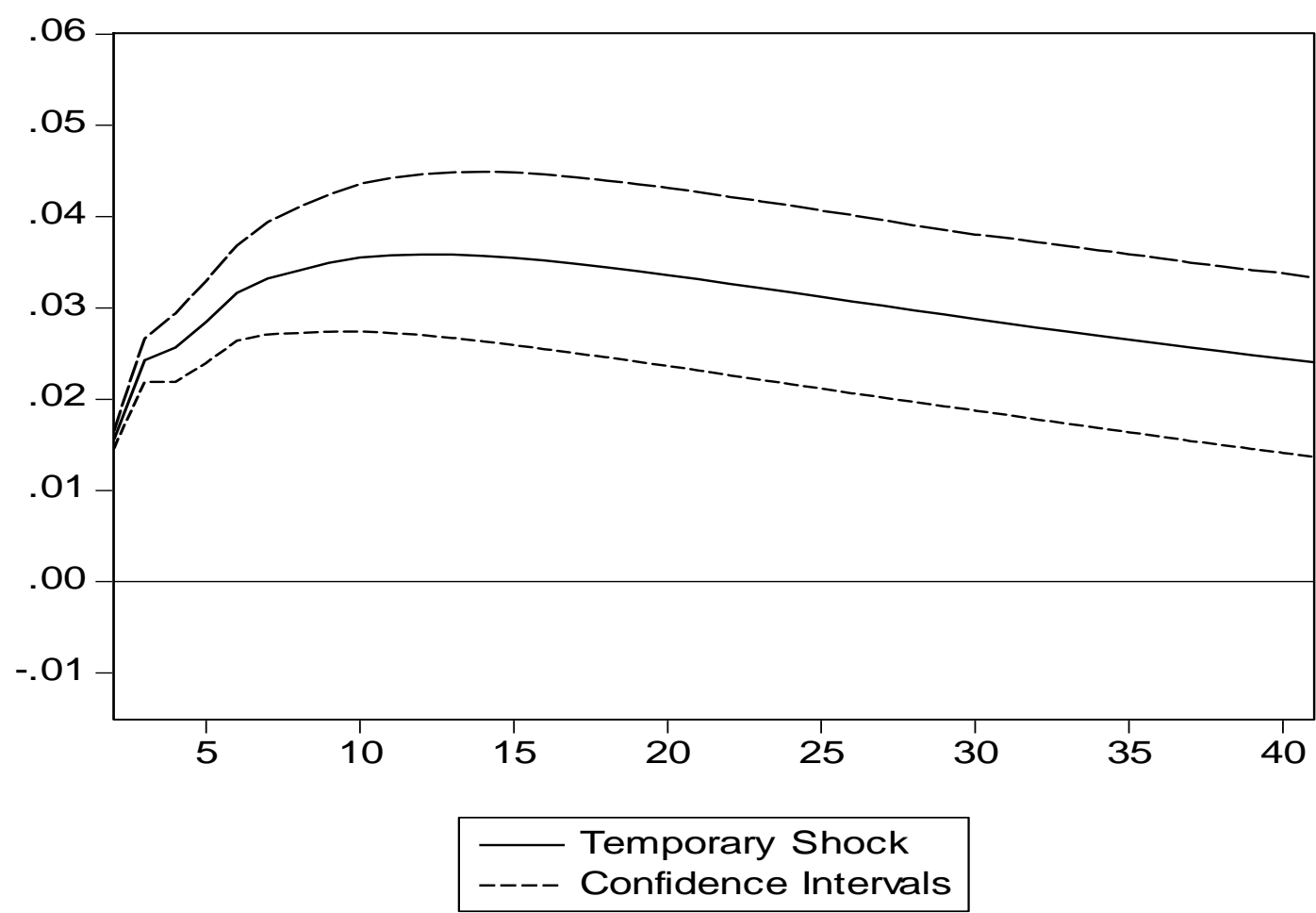


Figure 1c

U.S.

Response of U.S. Real House Prices to a Permanent Shock

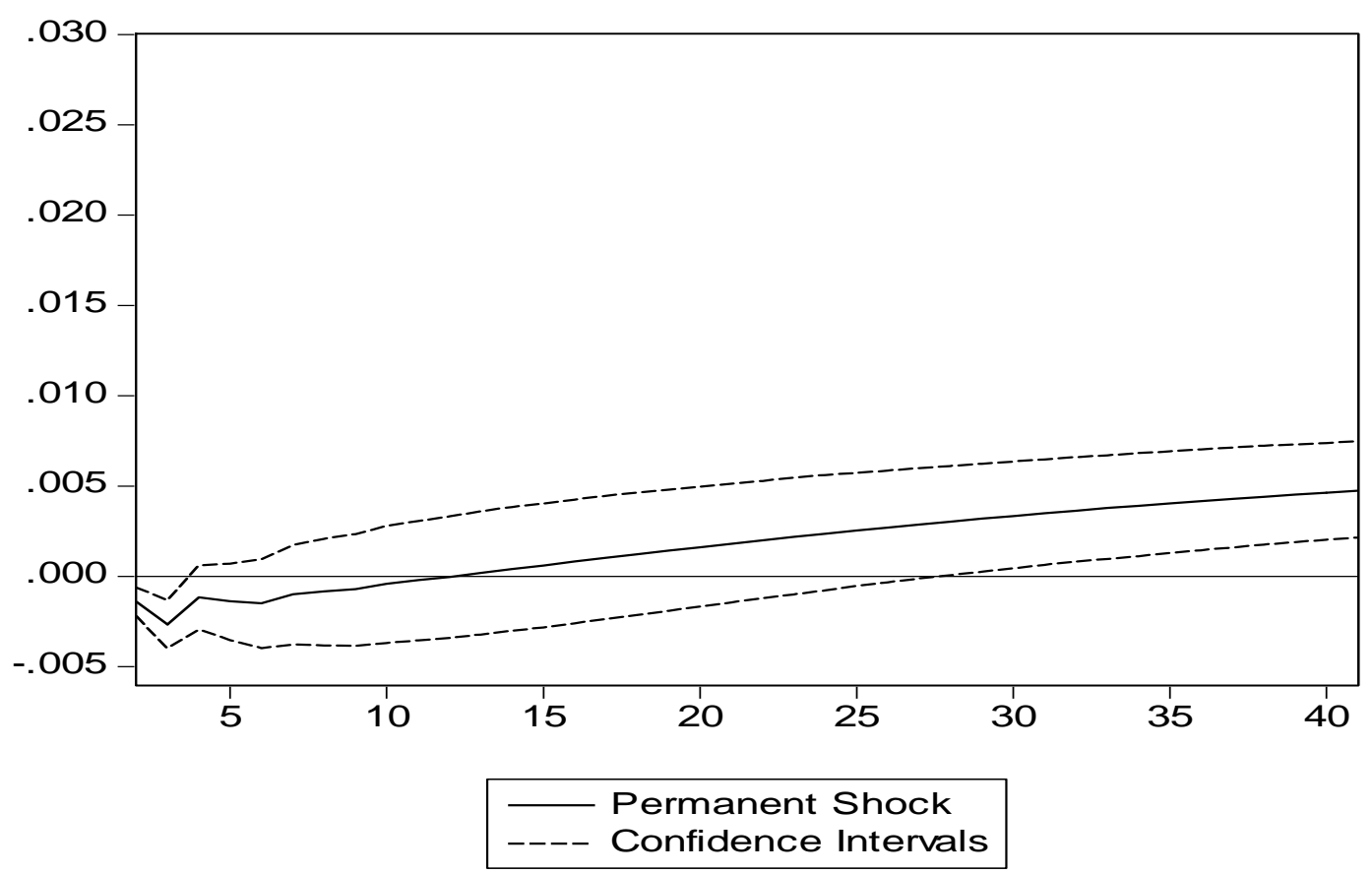

Response of U.S. Real House Prices to a Temporary Shock

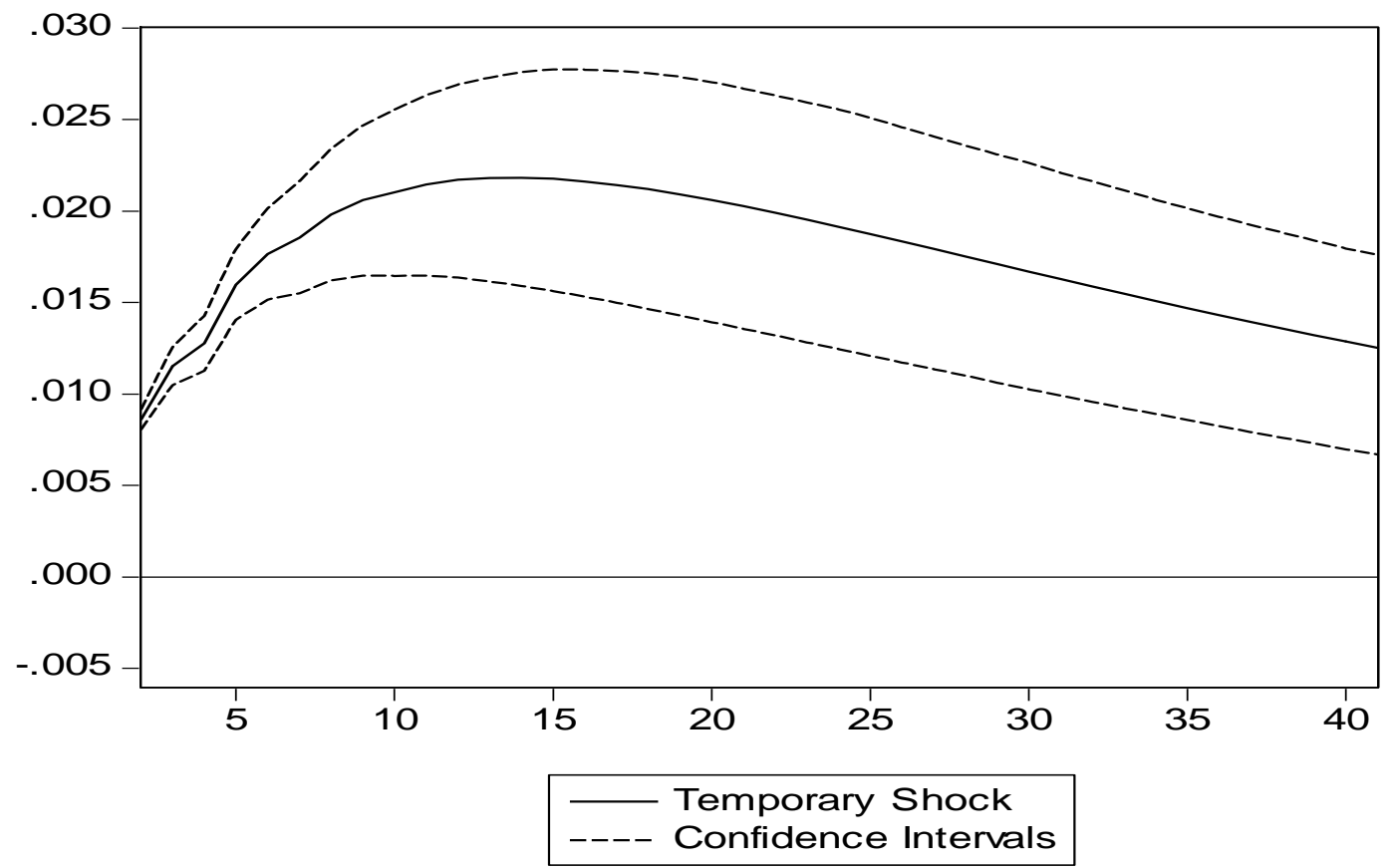


Figure 2a

N.Z.

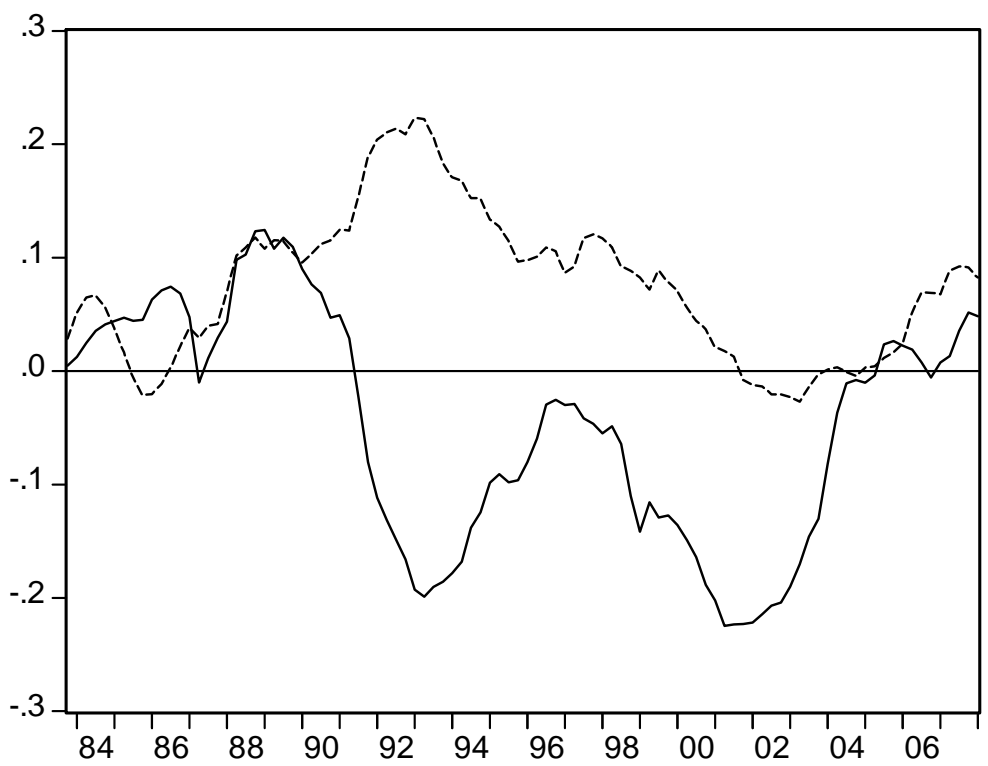

Permanent Component of N.Z. Real House Prices

Temporary Component of N.Z. Real House Prices

Figure $2 b$

U.K.

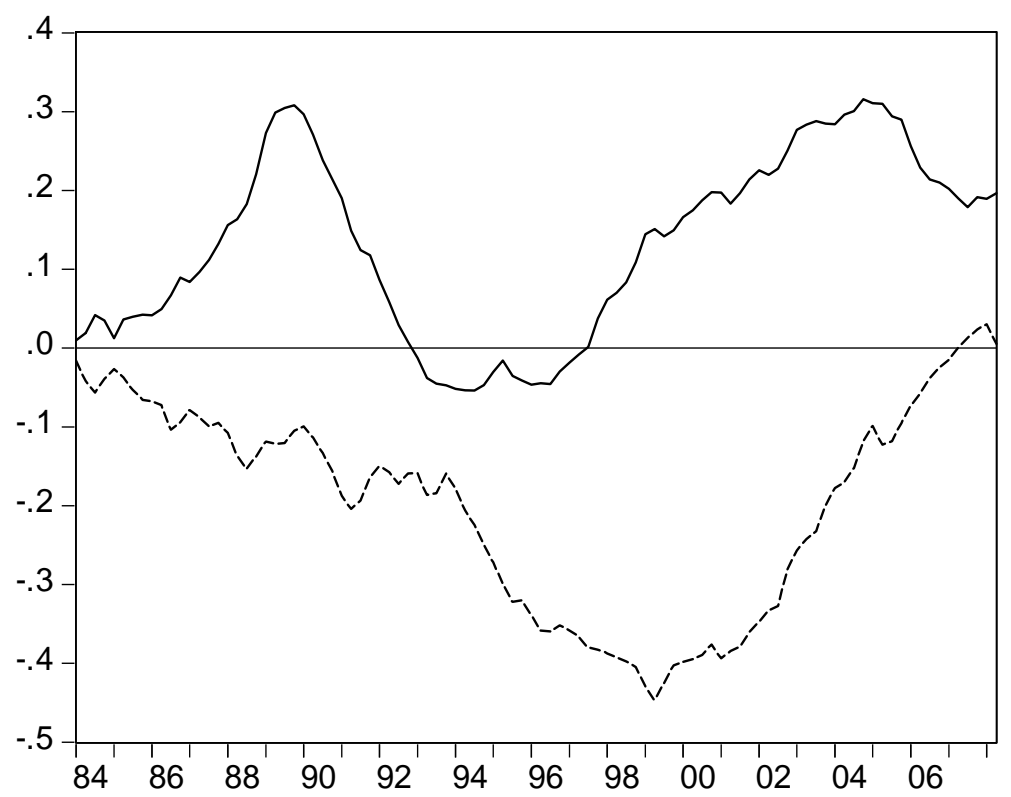

Permanent Component of U.K. Real House Prices Temporary Component of U.K. Real House Prices 
Figure 2c

U.S.

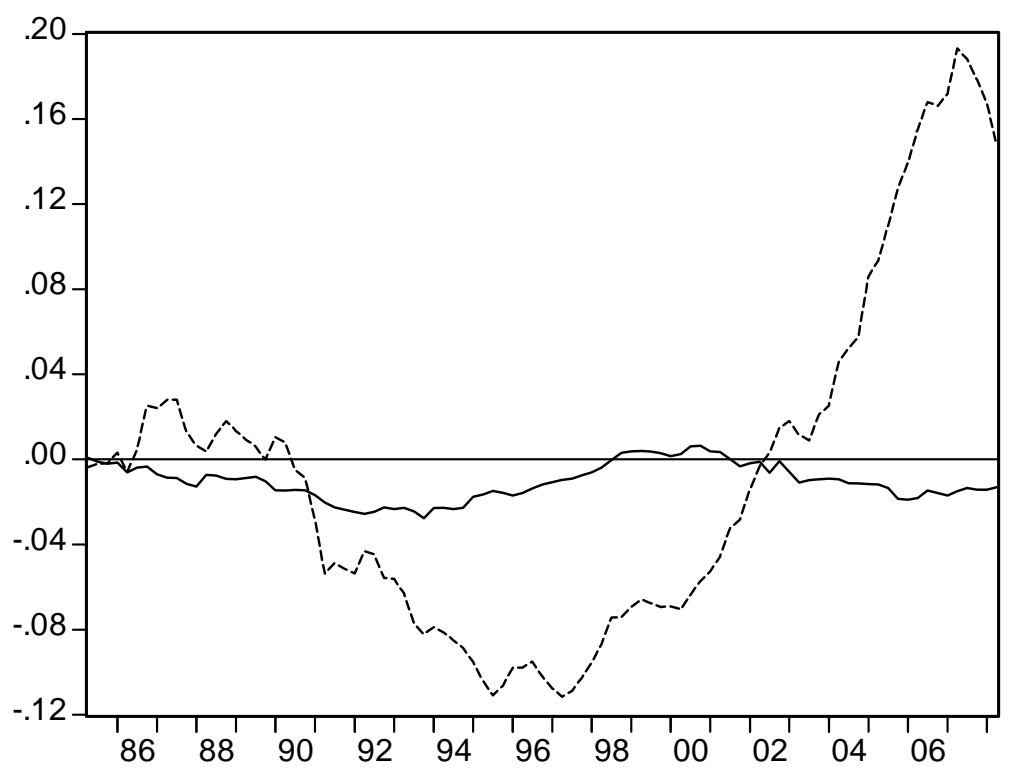

Permanent Component of U.S. Real House Prices Temporary Component of U.S. Real House Prices 
Figure 3a

N.Z.

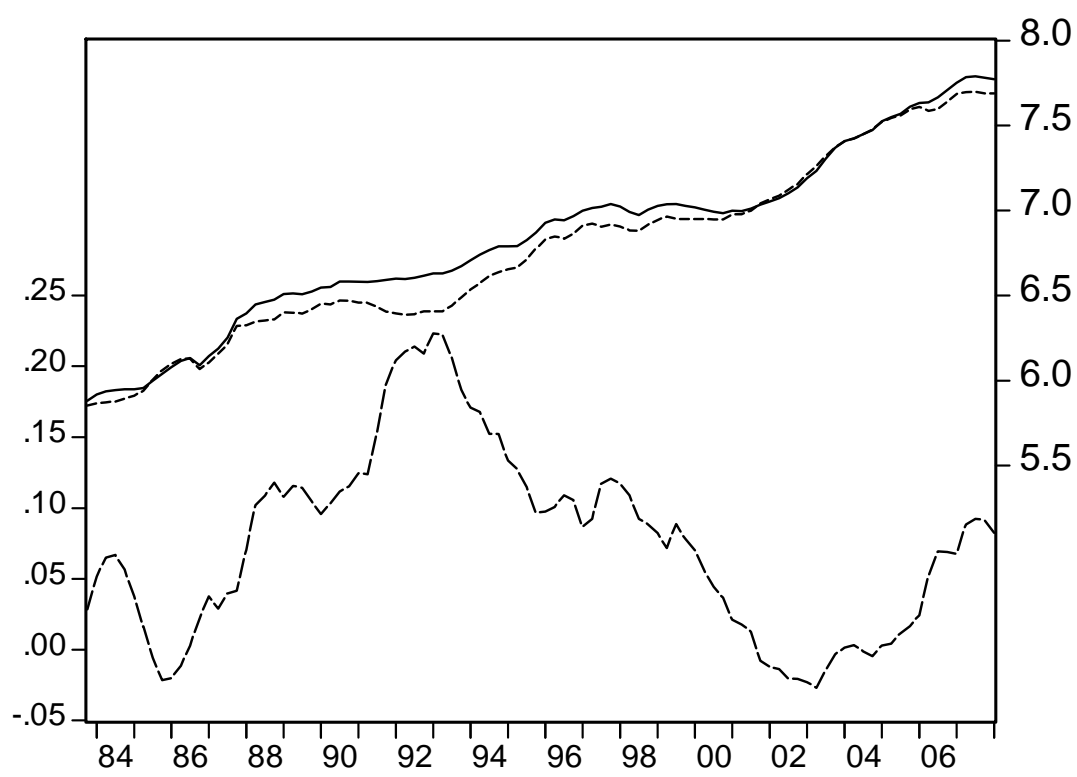

N.Z. (log) Real House Prices

Deterministic plus Permanent Component of N.Z. Real House Prices Temporary Compnent of N.Z. Real House Prices

Figure 3b

U.K.

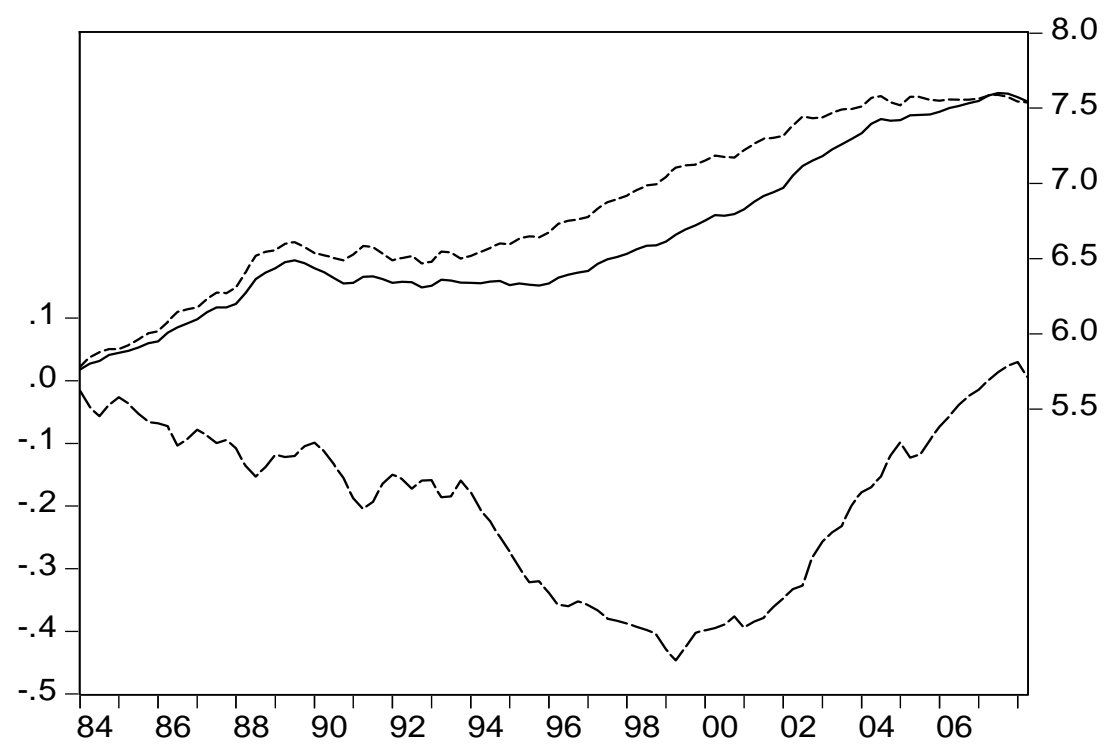

U.K. (log) Real House Prices

Determinisic Plus Permanent Component of U.K. Real House Prices

- - Temporary Component of U.K. Real House Prices 
Figure 3c

U.S.

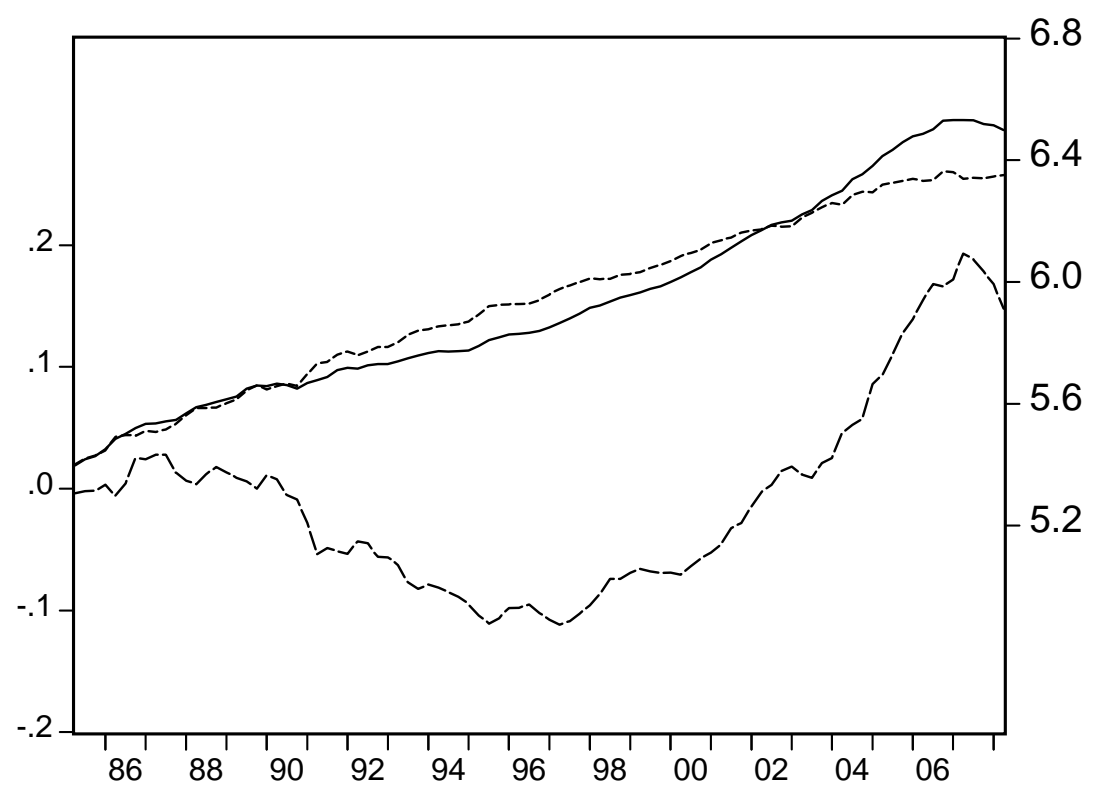

U.S. (log) Real House Prices

Deterministic plus Permanent Component of U.S. Real House Prices

Temporary Component of U.S. Real House Prices 